\title{
Sorption Recovery of Platinum Metals from Production Solutions of Sulfate-Chloride Leaching of Chromite Wastes
}

\author{
Georgiy Petrov, Irina Zotova, Tatiana Nikitina and Svetlana Fokina *(D) \\ Department of Metallurgy, Faculty of Mineral Processing, Saint Petersburg Mining University, \\ 199106 St. Petersburg, Russia; Petrov_GV@pers.spmi.ru (G.P.); Zotova_IE@pers.spmi.ru (I.Z.); \\ Nikitina_TYu@pers.spmi.ru (T.N.) \\ * Correspondence: fokina_sb@pers.spmi.ru; Tel.: +7-921-592-26-08
}

check for updates

Citation: Petrov, G.; Zotova, I.; Nikitina, T.; Fokina, S. Sorption Recovery of Platinum Metals from Production Solutions of SulfateChloride Leaching of Chromite Wastes. Metals 2021, 11, 569. https://doi.org/10.3390/met11040569

Academic Editor: Jean-François Blais

Received: 17 March 2021

Accepted: 26 March 2021

Published: 1 April 2021

Publisher's Note: MDPI stays neutral with regard to jurisdictional claims in published maps and institutional affiliations.

Copyright: (c) 2021 by the authors. Licensee MDPI, Basel, Switzerland. This article is an open access article distributed under the terms and conditions of the Creative Commons Attribution (CC BY) license (https:/ / creativecommons.org/licenses/by/ $4.0 /)$.

\begin{abstract}
This paper discusses the scientific rationale for methods of platinum metals sorption centralization from saturated solutions with a high content of macrocomponents. Methods of sorption centralization of platinum and iridium using local anionites such as AH-31, AB-17-8, Purolite S985 are described. The sorbents used were conditioned to remove organic and mineral impurities. The sorption isotherms of platinum group metals $1 / \mathrm{EC}=\mathrm{f}(1 / \mathrm{Cp})$ at a temperature of $20^{\circ} \mathrm{C}$ and a duration of $24 \mathrm{~h}$ were plotted. The data on the sorption recovery of platinum and iridium from individual and combined sulfate-chloride solutions were determined. Isotherms of iridium sorption from sulfate-chloride solution are formed. Results of the apparent sorption equilibrium constant and values of standard Gibbs energy $(\Delta \mathrm{G}, \mathrm{kJ} / \mathrm{mol})$ of ion exchange for sorption of platinum and iridium from individual and combined sulfate-chloride solutions are presented. Linearized isotherms and kinetic curves of joint sorption of platinum and iridium from sulfate-chloride solution are described. Comparative sorption of the platinum-group metals (PGM) by anionites AB-17-8 and Purolite S985 from sulfate-chloride solutions is shown. The sorption diagram of platinum and iridium from sulfatechloride product solutions is presented. It has been revealed that complete recovery is achieved using chelation ion-exchange resin Purolite S985, with recovery of Pt up to 95\% and Ir more than $73 \%$. The sorption process is accompanied by intradiffusion constraints that are confirmed by the analysis of kinetic curves using Schmukler and Boyd-Adams models.
\end{abstract}

Keywords: platinum metals; sulfate-chloride solutions; sorption

\section{Introduction}

Advanced hydrometallurgical technologies of platinum-containing material processing and platinum-group metals (PGM) refining are based on the use of processes running mainly in chloride and sulfate-chloride media. They are focused on collective transfer of noble metals into solution [1-5]. Their subsequent recovery and, moreover, selection are complicated by low content and the complex nature of the complex formation due to the formation of mono- and polynuclear compounds with different kinetic activity [6,7].

Among all available operations for the recovery of platinum satellite metals from solutions, sorption is widespread, and seems a relatively simple, cost-effective, and environmentally friendly method [2]. The selection of sorbents able to perform ionic exchange of nonferrous metals from solutions of different compositions is quite large [8-11].

Recently, sorbents produced by Purolite (Rhondda Cynon Taff, UK) have been studied and introduced more and more actively. The most interesting in terms of sorption of platinum metals that are in the form of chloride and sulfate complexes are resins of S-985 (polyamine functional group), S-920 (thiourea functional groups), S-108 (amine functional group), and S-930 (aminodiacetic chelating functional groups). These sorbents have a high selectivity to platinum metals and good sorption characteristics. They are recommended for the separation of platinoids from non-ferrous metals present in process solutions in large amounts $[12,13]$. Reportedly, local anionites are possible to use, such as AB-17-8 and 
AN-31, which are characterized by high selectivity and strength of element binding during sorption from process solutions $[14,15]$. The degree of platinum metal oxidation, aquation, and hydrolysis processes occurring in the system has a great impact on the sorption of sulfate and chloride complexes of platinoids by anionites [16-20].

The reuse of mining waste deposits of noble metals (concentration tailings, hydrometallurgical slimes, etc.) is usually associated with the processing of highly dispersed low-grade raw materials with a high content of rock-forming minerals and iron [21-27]. Under intensive sulfate-chloride oxidation leaching, quantitative interphase separation of macro components and noble metals does not seem possible [28]. In this regard, the development of scientifically based methods of sorption concentration of platinum metals from saturated sulfate-chloride solutions with a high content of macrocomponents is of current interest, in particular, as part of the hydrometallurgical solution of low-grade mining waste materials processing that meets today's requirements of technical and economic efficiency and environmental safety.

\section{Materials and Methods}

The initial concentrations, medium acidity, and temperature selected are based on the approximation of the experiment to the real conditions that occur during the processing of platinum metal mining wastes by heap leaching, in particular, wastes from chromite concentration (PGM total is $0.3-0.5 \mathrm{~g} / \mathrm{t}$ ).

In this paper, the sorbent agents AH-31 (Uralchimplast, Nizny Tagil, Russia), AB17-8 (Ural Chemical Company, Sredneuralsk, Russia), and Purolite S985 (Purolite ltd, Rhondda Cynon Taff, UK) were selected for sorption concentration of platinum and iridium. Their characteristics are presented in Table 1 below. The Table 1 contains the following abbreviations: AC - acrylic, MP - macroporous, G - gel, QAB - quaternary ammonium base, $\mathrm{PP}$ - polyethylene polyamine, AA - secondary and tertiary aliphatic amino groups, SEC static exchange capacity.

Table 1. Ion-exchange resins characteristics.

\begin{tabular}{ccccc}
\hline Ionite & Type & Physical Structure & Functional Groups & SEC for Cl$^{-}$mmol/g \\
\hline AB-17-8 & strong base & G & QAB & 3.4 \\
Purolite S 985 & weakly basic & MP & polyamines & 2.1 \\
AH-31 & weakly basic & G & AA & 2.8 \\
\hline
\end{tabular}

Before testing, the sorbents were conditioned to remove organic and mineral impurities. At the first stage, Russian ion-exchange resins were placed for $24 \mathrm{~h}$ in saturated sodium chloride solution (up to three volumes) for uniform expanding. During subsequent stages, consistent washing was carried out according to the following procedure: alternate treatment of ion-exchanger resins with $1,1.5$, and $2 \mathrm{M}$ of $\mathrm{HC} 1$ and $\mathrm{NaOH}$ solutions and ethanol. Purolite S985 resin was placed in saturated sodium chloride solution for uniform expanding and then treated with $1 \mathrm{M}$ of $\mathrm{HCl}$ solution $\left(2 \mathrm{~V}_{\mathrm{HCl}}-1 \mathrm{~V}_{\text {resin }}\right)$. The ionite washed with distilled water was treated with $1 \mathrm{M}$ of $\mathrm{NaOH}$ solution $\left(2 \mathrm{~V}_{\mathrm{NaOH}}-1 \mathrm{~V}_{\text {resin }}\right)$ and ethyl alcohol $\left(1 \mathrm{~V}_{\text {alcohol }}-1 \mathrm{~V}_{\text {resin }}\right)$. Then the anionites were converted into chloride form by passing them through $1 \mathrm{M}$ of hydrochloric acid solution to full saturation.

The initial iridium solution was prepared using the sintering method with barium peroxide from pure iridium powder. The sample was carefully ground with five times the amount of peroxide by weight. The mixture of iridium powders was sintered at $800-900{ }^{\circ} \mathrm{C}$ for $2 \mathrm{~h}$ followed by dissolving the sinter in hydrochloric acid when heated. The initial iridium concentration was $3.61 \mathrm{~g} / \mathrm{L}$. The content of trace impurities in the solution, including barium, was lower than the sensitivity of the analysis. Analysis of the spectrogram of iridium chloride solution obtained using an LEKI SS1207 spectrophotometer indicated the co-presence of $\operatorname{Ir}(\mathrm{III})$ and $\operatorname{Ir}(\mathrm{IV})$ complexes in the percentage correlation 85:15. 
An initial working solution of platinum was prepared by dissolving chloroplatinic acid in concentrated hydrochloric acid. The initial concentration of $\mathrm{Pt}$ (II), IV) complexes was $1.66 \mathrm{~g} / \mathrm{L}$.

For sorption concentration, the initial concentrations of platinum and iridium were $0.26 \mathrm{mmol} / \mathrm{L}$. $\mathrm{HCl}$ and $\mathrm{H}_{2} \mathrm{SO}_{4}$ concentrations were $0.5 \mathrm{~mol} / \mathrm{L}$ at their molar ratio of 1:1 [29]. The volume of solutions varied from 25 to $100 \mathrm{~mL}$. The duration of the experiments was 15-90 min and $24 \mathrm{~h}$.

For quantification of the sorption equilibria in the experiments, anionite samples $(1 \mathrm{~g})$ were stirred in sulfate-chloride solutions $(50 \mathrm{~mL}$ ). After $24 \mathrm{~h}$, the PGM concentrations in the equilibrium solutions were determined. Then, the sorbent exchange capacity (EC, $\mathrm{mmol} / \mathrm{g}$ ), distribution coefficient (D), PGM recovery into the sorbent $(\mathrm{R}, \%)$, and separation coefficient (S) were calculated using the following equations:

$$
\begin{gathered}
\mathrm{EC}=\frac{\left(\mathrm{C}_{0}-\mathrm{C}_{\mathrm{E}}\right) \cdot \mathrm{V}}{\mathrm{q}} \\
\mathrm{D}=\frac{\mathrm{EC}}{\mathrm{C}_{\mathrm{E}}} \\
\mathrm{R}=\frac{\left(\mathrm{C}_{0}-\mathrm{C}_{\mathrm{E}}\right) \cdot 100 \%}{\mathrm{C}_{0}} \\
\mathrm{~S}=\frac{\mathrm{D}_{1}}{\mathrm{D}_{2}}
\end{gathered}
$$

where $C_{0}$ is the concentration of PGM in the initial solution in mmol/L; $C_{E}$ is the equilibrium concentration of $\mathrm{PGM}$ in solution after sorption in $\mathrm{mmol} / \mathrm{L} ; \mathrm{V}$ is the volume of the solution in $\mathrm{l}$; and $\mathrm{q}$ is the ionite suspension in $\mathrm{g}$.

Using the method of molar ratio variation of ionic compounds $(1 \mathrm{~g})$ and solutions (25, $50,75$, and $100 \mathrm{~mL})$, sorption isotherms of $\mathrm{PGM} 1 / \mathrm{EC}=\mathrm{f}\left(1 / \mathrm{C}_{\mathrm{E}}\right)$ at $20^{\circ} \mathrm{C}$ and a duration of $24 \mathrm{~h}$ were plotted [30,31]. The Langmuir sorption isotherm equation was used for the quantification of experimental sorption curves [32-34].

The formal criteria of the Schmukler, Boyd-Adams, and Morris-Weber models were used to establish the type of kinetics of the ion-exchange process in the systems under study $[35,36]$.

\section{Results and Discussion}

Based on the analysis of the experimental findings on sorption from sulfate-chloride solutions, the following series of sorbability for the complexes Pt (II, IV) and Ir (III, IV) can

\begin{tabular}{|c|c|c|c|c|c|c|}
\hline \multirow{2}{*}{$\begin{array}{c}\text { Ionite } \\
\begin{array}{c}\text { Quantitative } \\
\text { Characteristics } \\
\text { of Sorption }\end{array}\end{array}$} & \multicolumn{3}{|c|}{ Individual Sorption } & \multicolumn{3}{|c|}{ Joint Sorption } \\
\hline & EC & D & $\mathbf{R}$ & EC & D & $\mathbf{R}$ \\
\hline \multicolumn{7}{|c|}{ platinum } \\
\hline AH-31 & 0.010 & 213.16 & 81 & - & - & - \\
\hline AB-17-8 & 0.011 & 334.62 & 87 & 0.010 & 188.10 & 79 \\
\hline Purolite S 985 & 0.012 & $\begin{array}{l}950.00 \\
\text { iridium }\end{array}$ & 95 & 0.011 & 262.50 & 84 \\
\hline AH-31 & 0.0078 & 78.21 & 61 & - & - & - \\
\hline AB-17-8 & 0.0086 & 101.52 & 67 & 0.007 & 57.14 & 54 \\
\hline Purolite S 985 & 0.0094 & 135.19 & 73 & 0.009 & 119.94 & 71 \\
\hline
\end{tabular}
be made for the ion exchangers: Purolite S985 > AB-17-8 > AN-31 (Table 2).

Table 2. Sorption recovery of platinum and iridium from individual and combined sulfate-chloride solutions: $\mathrm{C}_{\mathrm{Me}}=0.26 \mathrm{mmol} / \mathrm{L} ; \mathrm{C}_{\mathrm{H} 2 \mathrm{SO} 4}=0.5 \mathrm{~mol} / \mathrm{L} ; \mathrm{C}_{\mathrm{HCl}}=0.5 \mathrm{~mol} / \mathrm{L} ; 24 \mathrm{~h}$. 
Convex isotherms of platinum and iridium ions sorption on anionites AH-31, AB-17-8, and Purolite S985 show that these sorbents have high selectivity in relation to complex anions of platinum metals in sulfate-chloride medium (Figures 1 and 2).

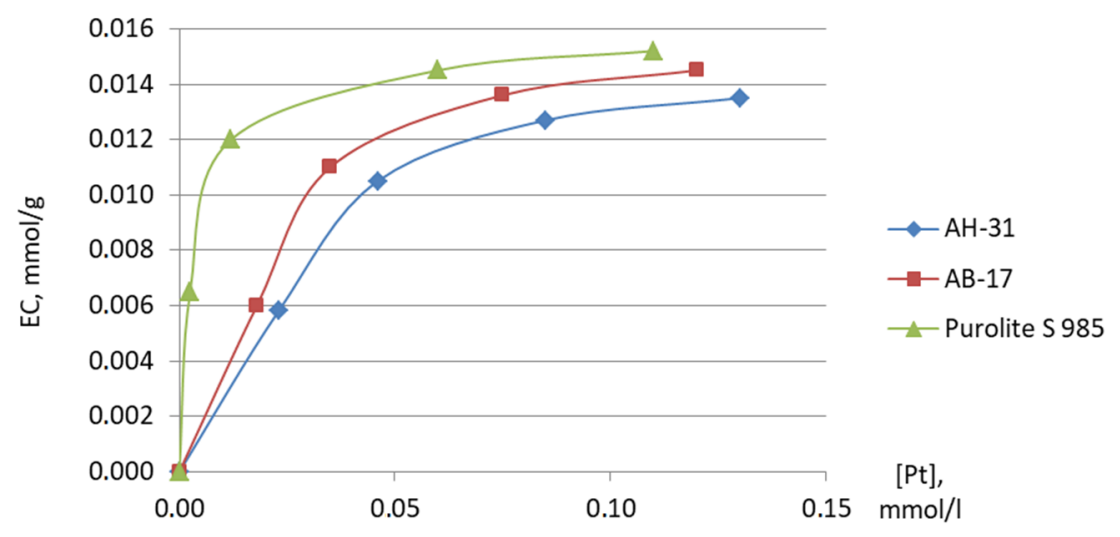

Figure 1. Isotherm of platinum sorption from sulfate-chloride solution: $\mathrm{C}_{\mathrm{Pt}}=0.26 \mathrm{mmol} / \mathrm{L}$; $\mathrm{C}_{\mathrm{H} 2 \mathrm{SO} 4}=0.5 \mathrm{~mol} / \mathrm{L} ; \mathrm{C}_{\mathrm{HCl}}=0.5 \mathrm{~mol} / \mathrm{L}$.

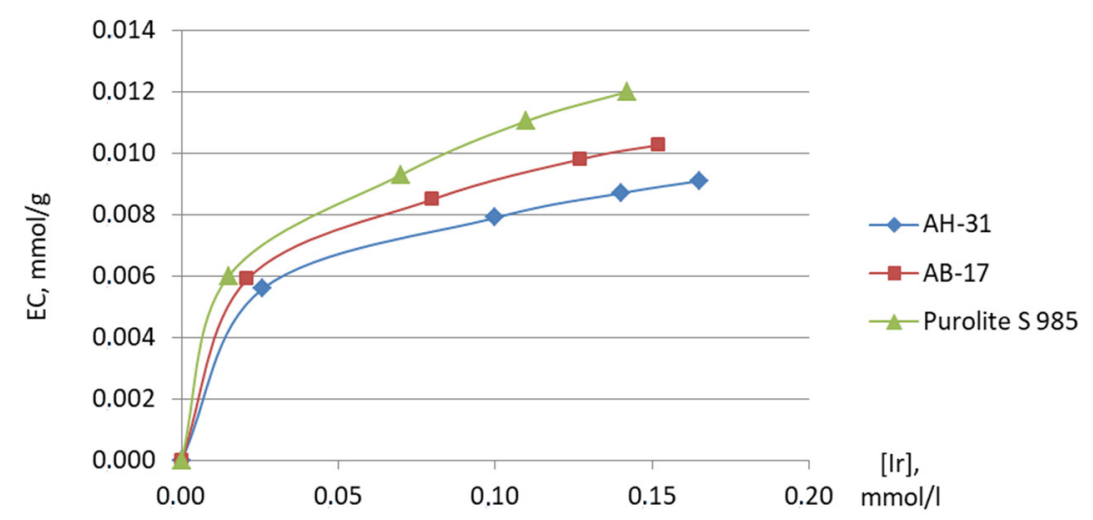

Figure 2. Isotherm of iridium sorption from sulfate-chloride solution: $\mathrm{C}_{\mathrm{Ir}}=0.26 \mathrm{mmol} / \mathrm{L}$; $\mathrm{C}_{\mathrm{H} 2 \mathrm{SO} 4}=0.5 \mathrm{~mol} / \mathrm{L} ; \mathrm{C}_{\mathrm{HCl}}=0.5 \mathrm{~mol} / \mathrm{L}$.

Based on the calculated values of the apparent constants of ion-exchange equilibria for individual sulfate-chloride solutions:

$$
\begin{aligned}
& \overline{\mathrm{RCl}}-\mathrm{Pt}(\mathrm{II}, \mathrm{IV})-\mathrm{HCl}-\mathrm{H}_{2} \mathrm{SO}_{4}-\mathrm{H}_{2} \mathrm{O} ; \\
& \overline{\mathrm{RCl}}-\mathrm{Ir}(\mathrm{III}, \mathrm{IV})-\mathrm{HCl}-\mathrm{H}_{2} \mathrm{SO}_{4}-\mathrm{H}_{2} \mathrm{O} ;
\end{aligned}
$$

where $\overline{\mathrm{RCl}}$ is anionite in chloride form. From this, it can be concluded that the affinity of ion exchangers $\mathrm{AH}-31$ and $\mathrm{AB}-17-8$ to iridium is greater than to platinum, while the sorbent Purolite S985 is quite the opposite. The obtained negative values of the standard Gibbs energy confirm the thermodynamic probability of ion-exchange recovery of PGM complexes from the studied individual sulfate-chloride solutions (Table 3).

In the case of the joint presence of platinum and iridium, its maximum recovery from sulfate and chloride solution is provided by anionite Purolite S985, which has higher sorption properties in comparison with AB-17-8 (Figure 3). Both tested sorbents are characterized by lower (by 15-30\%) iridium concentration in comparison with platinum (Table 2). 
Table 3. Apparent constants of sorption equilibria, regression coefficients and standard Gibbs energy values of ion exchange of platinum and iridium sorption from individual and combined sulfate-chloride solutions.

\begin{tabular}{|c|c|c|c|c|c|c|}
\hline Ionite & \multicolumn{3}{|c|}{ Individual Sorption } & \multicolumn{3}{|c|}{ Joint Sorption } \\
\hline $\begin{array}{c}\text { Thermodynamic } \\
\text { Parameters } \\
\text { of Sorption }\end{array}$ & $\mathbf{K}$ & $\mathbf{R}^{2}$ & $\Delta \mathrm{G}, \mathrm{kJ} / \mathrm{mol}$ & $\mathbf{K}$ & $\mathbf{R}^{2}$ & $\Delta \mathrm{G}, \mathrm{kJ} / \mathrm{mol}$ \\
\hline & & & platinum & & & \\
\hline AH-31 & 16.02 & 0.986 & -6.76 & - & - & - \\
\hline AB-17-8 & 20.4 & 0.9376 & -7.36 & 27.27 & 0.9934 & -8.05 \\
\hline Purolite S 985 & 153.84 & 0.9861 & $\begin{array}{l}-12.27 \\
\text { iridium }\end{array}$ & 67.67 & 0.9788 & -10.27 \\
\hline AH-31 & 47.95 & 0.9796 & -9.43 & - & - & - \\
\hline AB-17-8 & 53.66 & 0.9821 & -9.70 & 20.83 & 0.9979 & -7.40 \\
\hline Purolite S 985 & 66.90 & 0.9681 & -10.24 & 27.34 & 0.997 & -8.06 \\
\hline
\end{tabular}

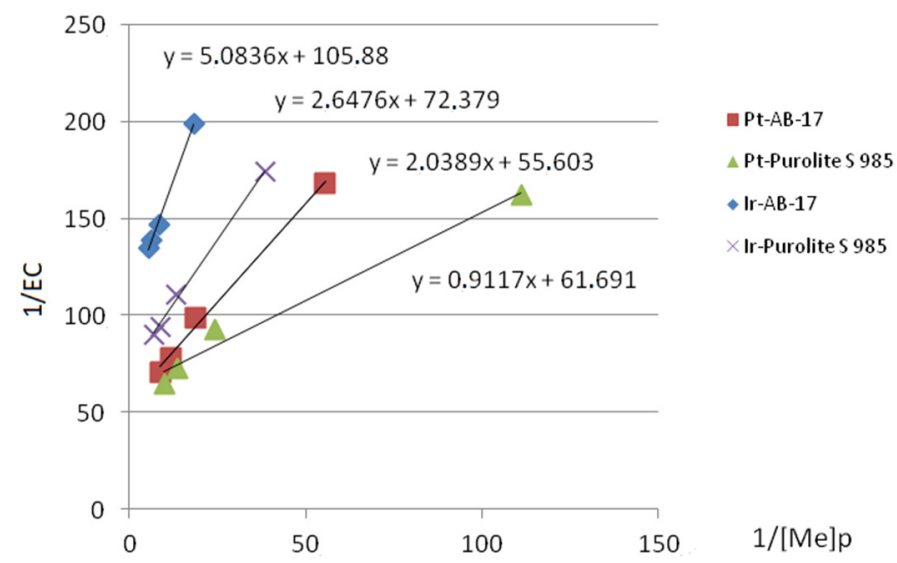

Figure 3. Linearized isotherms of platinum and iridium joint sorption from sulfate-chloride solution: $\mathrm{C}_{\mathrm{Me}}=0.26 \mathrm{mmol} / \mathrm{L} ; \mathrm{C}_{\mathrm{H} 2 \mathrm{SO} 4}=0.5 \mathrm{~mol} / \mathrm{L} ; \mathrm{C}_{\mathrm{HCl}}=0.5 \mathrm{~mol} / \mathrm{L}$.

In general, the trends observed for its individual sorption remain. In particular, the affinity of the chelation resin Purolite S985 to platinum is shown to a greater extent than to iridium. The competitive advantage of platinum can be explained by the lower degree of hydration of its anions and higher kinetic lability in comparison with iridium anions (Table 3).

The rate of joint sorption concentration of platinum and iridium during the first seconds of contact is very high, and it decreases as the anionites become saturated. It should also be noted that, for the studied anionites, during $15 \mathrm{~min}$, the degree of saturation with $\mathrm{Pt}$ ions is from 0.45 to 0.55 , and Ir is from 0.31 to 0.42 , respectively, when using AB-17-8 and Purolite S985.

The analysis performed of the sorption curves (Figure 4) using given kinetic models allows assuming interdiffusion limitations during joint platinum and iridium sorption for both anionites, which is confirmed by linear dependence for the Schmukler gel kinetics model $\left(\mathrm{R}^{2}=0.991-0.932\right)$ and the non-linear character of the external diffusion Boyd-Adams model $\left(\mathrm{R}^{2}=0.891-0.903\right)$.

In order to determine the process parameters of sorption and to study the effect of macrocomponents, solutions were used that were similar in composition to the production sulfate-chloride leaching solutions of platinum-bearing chromite concentration tailings. Their composition was as follows (in g/L): $25 \mathrm{NaCl}, 25 \mathrm{HCl}, 25 \mathrm{H}_{2} \mathrm{SO}_{4}, 3.4 \mathrm{Fe}, 1.2 \mathrm{Mg}$, $5.6 \mathrm{mg} / \mathrm{L} \mathrm{Pt}, 1.2 \mathrm{mg} / 1 \mathrm{Ir}$. Sorption $\left(2 \mathrm{~h}, 20^{\circ} \mathrm{C}\right)$ was performed under static conditions using sorbents Purolite S985 and AB-17-8. Before sorption, the studied solutions were saturated with chlorine gas (up to $3.7 \mathrm{~g} / \mathrm{L} \mathrm{Cl}_{2}$ ). 


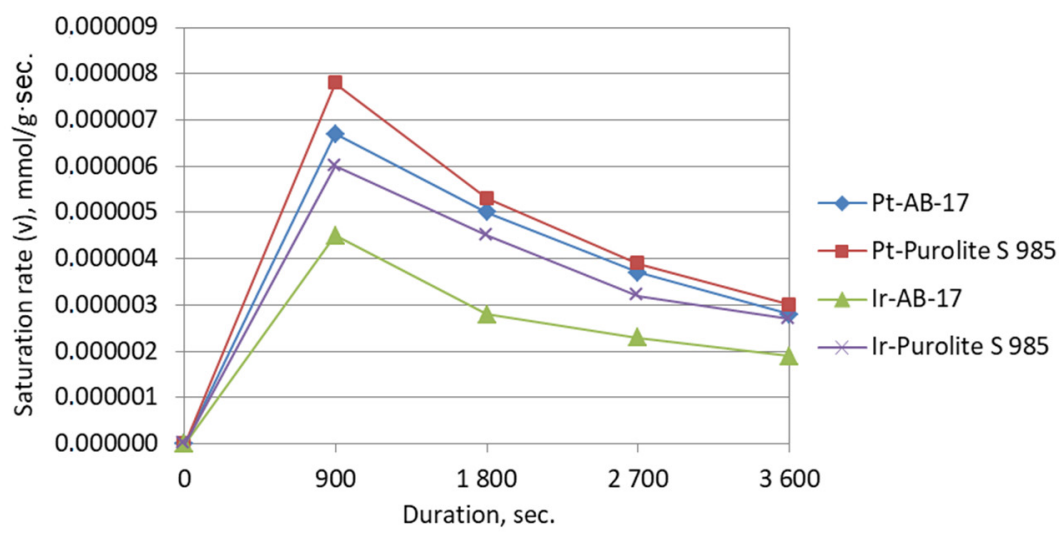

Figure 4. Kinetic curves of platinum and iridium joint sorption from sulfate-chloride solution: $\mathrm{C}_{\mathrm{Me}}=0.26 \mathrm{mmol} / \mathrm{L} ; \mathrm{C}_{\mathrm{H} 2 \mathrm{SO} 4}=0.5 \mathrm{~mol} / \mathrm{L} ; \mathrm{C}_{\mathrm{HCl}}=0.5 \mathrm{~mol} / \mathrm{L}$.

It can be noted that platinum sorption in the presence of iron and magnesium is the most complete, using anion-exchange resin Purolite S985; yet, at minimum sorbent consumption of $0.5 \mathrm{~g} / \mathrm{L}$, its recovery into the sorbent is more than $80 \%$ (Figures 5 and 6 ).

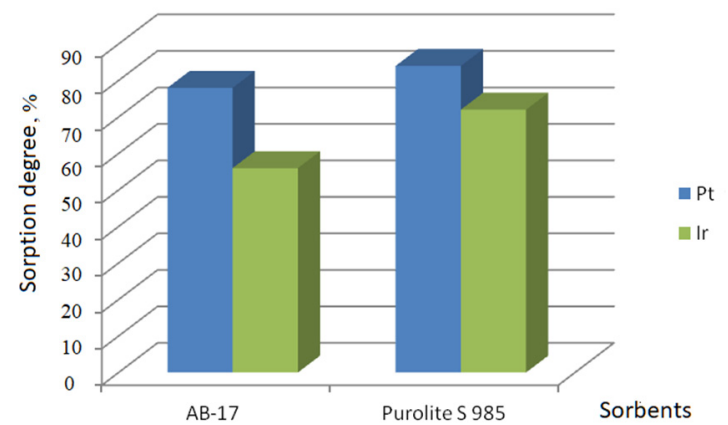

Figure 5. PGM comparative sorption using anionites AB-17-8 and Purolite $\mathrm{S} 985$ from sulfate-chloride solutions. Solution composition, g/L: $25 \mathrm{NaCl}, 25 \mathrm{HCl}, 25 \mathrm{H}_{2} \mathrm{SO}_{4}, 3.4 \mathrm{Fe}, 1.2 \mathrm{~g} / \mathrm{L} \mathrm{Mg}$, $5.6 \mathrm{mg} / \mathrm{L} \mathrm{Pt}$, $1.2 \mathrm{mg} / \mathrm{L}$ Ir. Sorbent consumption of $2 \mathrm{~g} / \mathrm{L}$.

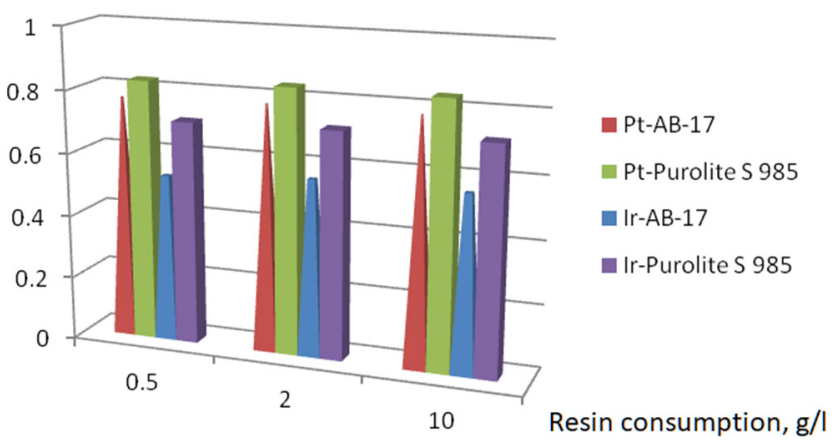

Figure 6. Platinum and iridium sorption from production sulfate-chloride solutions. Solution composition, g/L: $25 \mathrm{NaCl}, 25 \mathrm{HCl}, 25 \mathrm{H}_{2} \mathrm{SO}_{4}, 3.4 \mathrm{Fe}, 1.2 \mathrm{~g} / \mathrm{L} \mathrm{Mg}, 5.6 \mathrm{mg} / \mathrm{L} \mathrm{Pt}, 1.2 \mathrm{mg} / \mathrm{L}$ Ir. Sorbent consumption of $0.5-10 \mathrm{~g} / \mathrm{L}$.

A similar sorption character is observed for iridium: when using AB-17-8, the recovery level into the sorbent is $15-20 \%$ lower than in the case of Purolite S985. Considering that there is no fundamental difference in the affinity of the studied anionites to platinum and iridium, it is expedient to extract PGM from the production sulfate-chloride solutions using collective sorption to produce the resin containing from 0.25 to $1 \%$ of PGM total. 
As a desorbent, hydrochloric acid solution (50-70 g/L) is the most reasonable due to its cost-efficiency, lower eluent requirement, and simultaneous regeneration of anionites (sorbents are converted into chloride form).

\section{Conclusions}

The low content of noble metals in the mining waste materials and the geotechnologies applied (heap, in situ, and other types of leaching), based on the use of sulfate-chloride media, suggest the use of selective methods of valuable components concentration from the production solutions, in particular, sorption by ion-exchange resins.

For sorption of platinum and iridium from individual and combined synthetic solutions, the most complete recovery is achieved when using chelation resin Purolite S985, with a recovery of $\mathrm{Pt}$ up to $95 \%$ and of Ir over $73 \%$. The sorption process is accompanied by interdiffusion limitations, which is confirmed by the analysis of kinetic curves using Schmukler and Boyd-Adams models.

The chromium content in the solutions similar to production ones from the chromite waste heap leaching is less than $2 \mathrm{mg} / \mathrm{l}$, which is due to the extremely low solubility of chromite, sulfates, and chromium chlorides in sulfate-chloride media and, accordingly, does not affect the sorption parameters. Considerable content of ferro-magnesium in the heap leaching solutions does not significantly affect the PGM behavior during sorption with Purolite S985 resin: platinum recovery into the sorbent exceeds $90 \%$, and iridium recovery $72 \%$. An increase in the anionite consumption from 0.5 to $10 \mathrm{~g} / \mathrm{L}$ is accompanied by an increase in the PGM recovery by $4-5 \%$ on average. When using Purolite S985, the total content of noble metals in the production resin achieves 0.25 to $1 \%$.

The high sorption performance can also be related to the higher kinetic lability of inert PGM complexes during saturation of the sulfate-chloride solution with chlorine during the leaching stage of platinum-containing tailings. Application of sulfate-chloride leaching of chromite concentration tailings, which are obtained during the processing of the Inagli and Konder deposits (Russian Platinum PLC, Aldan region, Russian Federation), with the subsequent ion-exchange sorption, will make it possible to produce a high-grade collective concentrate of noble metals.

Author Contributions: Conceptualization, G.P. and S.F.; methodology, I.Z.; software, T.N.; validation, I.Z., T.N., and S.F.; formal analysis, I.Z.; investigation, T.N.; resources, T.N.; data curation, S.F.; writing-original draft preparation, G.P.; writing-review and editing, G.P.; visualization, T.N.; supervision, G.P.; project administration, S.F.; funding acquisition, G.P. All authors have read and agreed to the published version of the manuscript.

Funding: This research received no external funding.

Data Availability Statement: Data is contained within the article.

Acknowledgments: The research was carried out with the involvement of the laboratory facilities of the Saint Petersburg Mining University Collective Use Center. The authors express their gratitude and appreciation to the staff of the departments of metallurgy of the Saint Petersburg Mining University for their attention, help, and support at different stages of writing the article.

Conflicts of Interest: The authors declare no conflict of interest.

\section{References}

1. Aleksandrova, T.N.; O'Connor, C. Processing of platinum group metal ores in Russia and south Africa: Current state and prospects. J. Min. Inst. 2020, 244, 462-473. [CrossRef]

2. Katsuhiro, N.; Toru, H.O. Platinum group metals production. In Treatise on Process Metallurgy; Seetharama, S., Ed.; Elsevier: Amsterdam, The Netherlands, 2014; pp. 1071-1097.

3. Saburbayeva, L.Y.; Boduen, A.Y.; Yu, P.S.; Ukraintsev, I.V. Study of pressure oxidation and bacterial leaching efficiency as a method of refractory gold concentrate breakdown. In Proceedings of the IMPC 2018-29th International Mineral Processing Congress, Moscow, Russia, 17-21 September 2018; pp. 2911-2921.

4. Aleksandrova, T.N.; Nikolaeva, N.V.; Lvov, V.V.; Romashev, A.O. Ore processing efficiency improvements for precious metals based on process simulations. Obogashchenie Rud. 2019, 2, 8-13. [CrossRef] 
5. Lvov, V.V.; Chitalov, L.S. Modern trends in the design of comminution processes and equipment for non-ferrous metals ores. Tsvetnye Metally. 2020, 10, 20-26. [CrossRef]

6. Buslaeva, T.M.; Simanova, S.A. The state of platinum metals in hydrochloric acid and chloride aqueous solutions. Palladium, platinum, rhodium, and iridium. J. Coord. Chem 1999, 25, 165-176.

7. Petrov, G.V. Concentration of Platinum Metals in the Processing of Traditional and Non-Traditional Platinum-Metal Raw Materials; St. Petersburg State Mining Institute: St. Petersburg, Russia, 2001; p. 106.

8. Zolotov, Y.A.; Varshal, G.M.; Ivanov, V.M. Analytical Chemistry of Platinum Group Metals: A Collection of Review Articles; KomKniga: Moscow, Russia, 2005; p. 592.

9. Zakharchenko, E.A.; Mokhodoeva, O.B.; Myasoedova, G.V. Use of fibrous "filled" sorbents for dynamic concentration of precious metals. Res. J. Sorpt. Chromatogr. Process. 2006, 6, 233-241.

10. Sipkina, E.I. Sorption materials for the extraction of platinum (IV) from chloride solutions. Appl. Chem. Biotechnol. 2015, 4, 7-15.

11. Cheremisina, E.; Cheremisina, O.; Ponomareva, M.; Bolotov, V.; Fedorov, A. Kinetic features of the hydrogen sulfide sorption on the ferro-manganese material. Metals 2021, 11, 90. [CrossRef]

12. Blokhin, A.A.; Abovsky, N.D.; Murashkin, Y.V.; Moloshneva, O.V.; Voronina, S.N. Sorption extraction of platinum and palladium from spent refining solutions with their low content. In Proceedings of the First International Congress and Exhibition NonFerrous Metals of Siberia-2009, Siberia, Russia, 8-10 September 2009; pp. 587-592.

13. Borbat, V.F.; Schindler, A.A.; Jarosik, I.S.; Semeonova, O.N.; Petrov, A.F.; Mikhaylenko, M. Extraction of platinum (IV), palladium (II) and rhodium (III) by sorption from solutions and pulps with Purolite resins. In Proceedings of the First International Congress and Exhibition Non-Ferrous Metals of Siberia-2009, Siberia, Russia, 8-10 September 2009; pp. 313-331.

14. Melnikov, N.D. Study of Ion-Exchange Equilibria and the Kinetics of Sorption of Platinum (II, IV) and Rhodium (III) in Chloride and Sulfate-Chloride Solutions for the Purpose of their Separation and Concentration. Ph.D. Thesis, University of Chemical Sciences, Irkutsk, 2013; p. 20.

15. Kononova, O.N.; Melnikov, A.M.; Borisova, T.V. Simultaneous sorption recovery of platinum and rhodium from sulfate-chloride solutions. Hydrometallurgy 2012, 117, 101-107. [CrossRef]

16. Kukushkin, Y.N. Chemistry of Coordination Compounds; Vysshaya Shkola: Moscow, Russia, 1985; p. 455.

17. Buslaeva, T.M. Chemistry and Technology of Platinum metals; Nauka: Moscow, Russia, 1999; p. 79.

18. Hartley, F.R. Chemistry of the Platinum Group Metals; Elsevier: Amsterdam, The Netherlands, 1991; p. 642.

19. Egorov, S.A.; Blokhin, A.A.; Murashkin, Y.V. Features of the sorption of rhodium (III) from chloride solutions on an ion exchange resin with thiouronium functional groups. Russ. J. Appl. Chem. 2020, 93, 1359-1365. [CrossRef]

20. Nikoloski, A.N.; Ang, K.-L.; Li, D. Recovery of platinum, palladium and rhodium from acidic chloride leach solution using ion exchange resins. Hydrometallurgy. 2015, 152, 20-32. [CrossRef]

21. Dodin, D.A. Platinometallnye Deposits of Russia. World Mineral Resource Base of Noble and Non-Ferrous Metals: 1970-2000-2025; Migachev: Saint-Petersburg, Russia, 2000; p. 753.

22. Dodin, D.A.; Izoitko, V.M. Superlarge man-made deposits of platinum metals. Obogashchenie Rud 2006, 6, 19-23.

23. Nikolaeva, E.; Talovina, I.; Nikiforova, V.; Heide, G. Chemical composition and genesis of serpentinite group minerals in nickeliferous weathering crust of the elov deposit (Urals). In Scientific and Practical Studies of Raw Material Issues; Proceedings of the Russian-German Raw Materials Dialogue: A Collection of Young Scientists Papers and Discussion, Saint-Petersburg, Russia; CRC: Boca Raton, FL, USA, 2019; pp. 3-10.

24. Ponomarenko, T.; Nevskaya, M.; Jonek-Kowalska, I. Mineral resource depletion assessment: Alternatives, problems, results. Sustainability 2021, 13, 862. [CrossRef]

25. Stepanov, S.Y.; Palamarchuk, R.S.; Kozlov, A.V.; Khanin, D.A.; Varlamov, D.A.; Kiseleva, D.V. Platinum-group minerals of Pt-placer deposits associated with the svetloborsky Ural-Alaskan type massif, middle Urals, Russia. Minerals 2019, 9, 77. [CrossRef]

26. Ivanik, S.A.; Ilyukhin, D.A. Flotation extraction of elemental sulfur from gold-bearing cakes. J. Min. Inst. 2020, 242, 202-208. [CrossRef]

27. Zaitsev, A.Y. Methodological approach to substantiation of capital investments of gold fields based on unit costs. J. Min. Inst. 2019, 238, 459-464. [CrossRef]

28. Fazlullin, M.I. Heap Leaching of Precious Metals; Publishing House of the Academy of Mining Sciences: Moscow, Russia, 2001; p. 647.

29. Fazlullin, M.I. Heap Leaching of Noble Metals; Mining Science Academy Publ.: Moscow, Russia, 2001; p. 647.

30. Kononova, O.N. Application of Chelated and Amphoteric Ionites in the Analysis and Technology of Rare Elements. Master's Thesis, Kurgan State University, Krasnoyarsk, Russia, 1981.

31. Helferich, F. Ionites. Fundamentals of Ion Exchange; Foreign Literature Publishing House: Moscow, Russia, $1962 ;$ p. 492.

32. Lee, I.-H.; Kuan, Y.C.; Chern, J.M. Equilibrium and kinetics of heavy metal ion exchange. J. Chin. Inst. Chem. Eng. 2007, 38, 71-84. [CrossRef]

33. Kokotov, Y.A.; Pasechnik, V.A. Equilibrium and kinetics of ion exchange. Chemistry 1970, 336.

34. Kononova, O.N. Chromatographic methods of separation and concentration. Master's Thesis, Krasnoyarsk State University, Krasnoyarsk, Russia, 1990. 
35. Billz, J.; Froelich, P. Kinetics and mechanisms of ion exchange on cheat-forming polymers. J. Phys. Chem. 1985, 3, 495-504.

36. Krizhanovskaya, O.O.; Sinyaeva, L.A.; Karpov, S.I.; Selemenev, V.F.; Borodin, E.V.; Rossner, F. Kinetic models for the description of the sorption of fat-soluble physiologically active substances by highly ordered inorganic silicon-containing polymers. Sorpt. Chromatogr. Process. 2014, 5, 784-794. 